\title{
Heterozygosis for CYP21A2 Mutation Considered as 21-Hydroxylase Deficiency in Neonatal Screening
}

\section{perspectives}

\author{
Fernanda Caroline Soardi \\ Sofia Helena V. Lemos-MarinI \\ FERNANDA BORCHERS COELI \\ Víctor Gonçalves Maturana \\ Márcia Duarte Barbosa da Silva \\ RENAN DARIN BERNARDI \\ Giselle ZeNKER JUSTO \\ Maricilda Palandi de-Mello
}

Centro de Biologia Molecular e Engenharia Genética (CBMEG), Universidade Estadual de Campinas (Unicamp) (FCS, FBC, VGM, MDBS, RDB, MPM);

Departamento de Pediatria $e$ Centro de Investigação em Pediatria, Faculdade de Ciências Médicas, Universidade Estadual de Campinas (Unicamp) (SHVLM), Campinas, SP, Brasil; Disciplina de Biologia Molecular, Departamento de Bioquímica, Universidade Federal de São Paulo (Unifesp) (GZJ), São Paulo, SP, Brasil.

Received in 25/8/2008 Accepted in 14/10/2008

\section{ABSTRACT}

Steroid 21-hydroxylase deficiency (21-OHD) accounts for more than $90 \%$ of congenital adrenal hyperplasia. CAH newborn screening, in general, is based on 17-hydroxyprogesterone dosage (17-OHP), however it is complicated by the fact that healthy preterm infants have high levels of 17-OHP resulting in false positive cases. We report on molecular features of a boy born pre-term $(\mathrm{GA}=30$ weeks; weight $=1,390 \mathrm{~g})$ with elevated levels of $17-\mathrm{OHP}(91.2 \mathrm{nmol} / \mathrm{L}$, normal $<40$ ) upon neonatal screening who was treated as having $\mathrm{CAH}$ up to the age of 8 months. He was brought to us for molecular diagnosis. Medication was gradually suspended and serum 17-OHP dosages mantained normal. The p.V281L mutation was found in compound heterozygous status with a group of nucleotide alterations located at the $3^{\prime}$ end intron 4 and $5^{\prime}$ end exon 5 corresponding to the splice site acceptor region. Molecular studies continued in order to exclude the possibility of a nonclassical 21-OHD form. The group of three nucleotide changes was demonstrated to be a normal variant since they failed to interfere with the normal splicing process upon minigene studies. (Arq Bras Endocrinol Metab 2008; 52/8:1388-1392)

Keywords: Neonatal screening; CYP21A2 mutations; Minigenes; 21-hydroxylase deficiency

\section{RESUMO}

Heterozigose para Mutação no Gene CYP21A2 Considerada como Deficiência de 21-Hidroxilase na Triagem Neonatal.

A deficiência de 21-hidroxilase (21-OHD) é uma doença autossômica recessiva que contribui com mais de $90 \%$ dos casos de hiperplasia congênita da adrenal. $\mathrm{O}$ teste de dosagem de 17-hidroxiprogesterona (17-OHP) por radioimunoensaio em amostras de sangue colhidas em papel de filtro tem sido 0 método mais usado nos programas de triagem neonatal. No entanto, essa triagem pode apresentar alto número de falso-positivos pelo fato de os recém-nascidos prematuros apresentarem dosagens mais elevadas deste esteróide. Apresentamos aqui os estudos moleculares de uma criança, sexo masculino, nascida pré-termo ( $\mathrm{IG}=30 \mathrm{sem}$; peso $=1.390 \mathrm{~g}$ ) que apresentava valores elevados de $17-\mathrm{OHP}$ sérica $(91,2 \mathrm{nmol} / \mathrm{L}$, normal $<40)$ na triagem neonatal e que foi tratada como portadora da forma clássica da 21-OHD até a idade de 8 meses quando nos foi encaminhada para diagnóstico molecular. A terapia foi, então, gradativamente descontinuada, sendo que as concentrações séricas de 17-OHP se mantiveram normais. A mutação p.V281L foi encontrada em heterozigose composta com um grupo de alterações no terminal $3^{\prime}$ do íntron 4 e no terminal $5^{\prime}$ do éxon 5 correspondendo à região do sítio aceptor de splicing. A análise do gene CYP21A2 prosseguiu para se excluir a possibilidade de a criança ser afetada com a forma não-clássica de 21-OHD. Pela análise de minigene ficou demonstrado que o grupo de três trocas nucleotídicas não afeta o processo normal de transcrição. Concluindo, a criança é apenas heterozigota da mutação p.V281L sem necessidade de tratamento. (Arq Bras Endocrinol Metab 2008; 52/8:1388-1392)

Descritores: Triagem neonatal; Mutações CYP21A2; Minigenes; Deficiência de 21-hidroxilase 


\section{INTRODUCTION}

teroid 21-hydroxylase deficiency (21-OHD; OMIM

+201910 ) is an autossomal disorder that accounts for more than $90 \%$ of congenital adrenal hyperplasia $(\mathrm{CAH})$ $(1,2)$. Impaired 21-hydroxylase activity results in decreased cortisol and aldosterone levels. Frequently, the classical 21-OHD causes ambiguous external genitalia at birth in females, precocious puberty in males, and acceleration of somatic growth in both sexes $(1,2)$. If the level of the enzyme impairment is higher than $99 \%$, mineralocorticoid synthesis is severely affected leading to salt-wasting crisis. Therefore, clinical symptoms may include failure to thrive, vomiting, hyperkalemia, hyponatremia, dehydration, metabolic acidosis $(1,2)$. The nonclassical form (NC) is characterized by late-onset manifestation and results from a mild deficiency of the enzyme. The excess of androgens presents different effects in nonclassical patients at any phase of postnatal development as pseudoprecocious puberty, hirsutism, acne, short stature, and decreased fertility (2).

21-OHD is caused by mutations on CYP21A2 gene that in general are derived from its adjacent pseudogene on chromosome $6 \mathrm{p} 21$. Either carriers for CYP21A2 mutations or NC patients with homozygous CYP21A2 mutations present an overlapping range for responses of 17-OHP levels upon ACTH test that varies, from values of $13 \mathrm{nmol} / \mathrm{L}$ up to $30 \mathrm{nmol} / \mathrm{L}$ (3). The higher value is generally considered as the lower limit for the diagnosis of the NC form $(4,5)$. However, this value is normally established before the identification of mutations in the CYP21A2 gene.

There is a high number of different techniques for diagnosing 21-OHD, but most CAH newborn screening is based on 17-hydroxyprogesterone radioimmunoassay on dried blood on filter paper (6-8). Nationwide and regional $\mathrm{CAH}$ screening programs have been introduced in several countries $(7,9,10)$ including in a few regions in Brazil $(11,12)$.

In the present study, we report the molecular features of a child that presented elevated level of 17-OHP in the neonatal screening, which was normalized within few months of age. The search for CYP21A2 mutations indicated compound heterozygosis for p.V281L mutation and a group of three nucleotide alterations located at the 3 '-end intron 4 and 5 '-end exon 5 corresponding to the splice site acceptor region. Molecular studies continued to exclude the possibility of this boy to develop a NC form of 21-OHD later. This group of alteration was demonstrated to be a normal variant since it failed to interfere with the normal splicing process upon minigene studies.

\section{SUBJECTS AND METHODS}

\section{Clinical report}

A Brazilian Caucasian male from non-consanguineous parents was born pre-term $(\mathrm{GA}=30$ weeks; weight $=$ 1,390 g; height $=40 \mathrm{~cm}$ ), after an in vitro fertilization triplet pregnancy. Upon 21-hydroxylase deficiency neonatal screening he presented high levels of 17-hydroxyprogesterone (17-OHP) $(91.2 \mathrm{nmol} / \mathrm{L}$, normal < $40)$. At the age of 27 days confirmatory test was performed and 17-OHP serum value was $73 \mathrm{nmol} / \mathrm{L}$ (normal 3,5 to 122). The child has never had dehydration or vomiting episodes. Also, failure to thrive was never observed. He was treated with hydrocortisone and was referred to our outpatient clinics when he was 8 months old for molecular studies because the parents were interested in pre-natal diagnosis in future pregnancies. The treatment was gradually suspended during four months in order to confirm the diagnosis. At the age of 22 months he was asymptomatic and his 17-OHP serum level was $2.2 \mathrm{nmol} / \mathrm{L}$ (normal 0.2 to 4.6 ). Normal growing and normal 17-OHP levels did not indicate the classical form of 21-hydroxylase.

\section{DNA extraction and analysis of the CYP21A2 gene}

This study was reviewed and approved by the appropriate Ethics Committee from Faculdade de Ciências Médicas at Universidade Estadual de Campinas (Unicamp, Campinas-SP, Brasil) and informed consent was obtained from the parents.

Genomic DNA samples from the child and his parents were obtained from peripheral blood by Proteinase $\mathrm{K}$ digestion and phenol/chloroform extraction following standard techniques (13). Cr21A2 large gene conversions and $30-\mathrm{kb}$ deletions were screened by Southern-blot (14). The eight most frequent pseudogene-derived mutations were investigated by ASOPCR (15). For sequencing experiments, CYP21A2 gene was amplified in two fragments, 5'UTR-exon 6 and exon 6-3'UTR, using specific CYP21A2 primers (15). The amplified fragments were purified with $\mathrm{Wi}-$ zard SV Gel and PCR Clean-UP System (Promega) and directly sequenced with Big Dye Terminator Cycle 
Sequencing Kit V3.1 Ready Reaction (ABI PRISM/PE Biosystems, Foster City, CA, USA) using the internal primers as previously described (16). Purified PCR products were sequenced in both sense and antisense orientations using ABI PRISM 3700 Automated DNA Sequencer according to the manufacturer's recommendations (ABI PRISM/PE Biosystems, Foster City, CA, USA). Nucleotide and amino acid numbering followed the published sequence by Higashi et al. (17) (NCBI \#M12792).

\section{Minigene construction, transfection and cDNA analysis}

A minigene with a fragment spanning from exon 2 to exon 6 was constructed. After the first amplification to select CYP21A2 gene, a nested-PCR was performed to construct the minigene with the following primers: Exon 2 sense-Xba I 5' - CCA GAT GTC TAG ATG ATG AAC TCC AAG - $3^{\prime}$ and Exon 6 antisense-Bam HI 5' - GTG GAT CCG AGG GGA GGC CGT -3'. The minigene amplification product was purified with Wizard SV Gel and PCR Clean-UP System (Promega, Madison, WI, USA) and digested with $X b a$ I and $B a m H$ I restriction enzymes. The digested fragment was ligated into a $\mathrm{BamHI}$ / Xba I opened pSVL vector (Pharmacia, Piscataway, NJ, USA). These constructions were transformed into E. coli $\mathrm{DH} 5 \alpha$ competent cells. Clones with the correct insert size (1,110 bp) were sequenced to verify their identity. Recombinant plasmids were transfected in COS-7 cells. Approximately $1 \times 10^{6}$ cells were plated in each $10 \mathrm{~cm}$ diameter tissue culture dish containing $8 \mathrm{~mL}$ DMEM medium (Invitrogen Carlsbad, CA, USA) supplemented with $10 \%$ fetal calf serum (FCS) and antibiotics. After 24 hours, COS-7 cell cultures were transfected with 10 $\mu \mathrm{g}$ of the construction using Lipofectamine 2000 (Invitrogen). Transfected cells were collected 24 hours after transfection and total RNA was isolated by use of RNeasy mini kit (Qiagen, Hilden, Germany), followed by DNase I (Invitrogen) digestion. First-strand synthesis was performed using $1 \mu \mathrm{L}$ of Improm II reverse transcriptase (Promega) according to the manufacturer's recommendations. The cDNA was amplified by PCR using the internal primers Ex3Ns Ex6 $\mathrm{Na}$ (15). PCR products were fractioned and isolated on a $1.5 \%$ agarose gel and the products were directly sequenced as described above with appropriate primers.

\section{RESULTS}

A child with high 17-OHP serum levels in the neonatal screening was referred to molecular investigation on CYP21A2 gene. Southern blot analysis from family members revealed neither $30-\mathrm{kb}$ deletions nor gene conversions (data not shown). However, upon screening for eight pseudogene-derived mutations by ASOPCR the heterozygosis for p.V281L mutation was observed. Segregation analysis performed by screening parents' DNA showed that the father was a carrier for p.V281L (Figure 1A). The mother's inherited allele, however, did not show any pseudogene-derived mutation. In order to characterize this allele, CYP21A2 direct sequencing analysis of the entire gene was performed. The group of alterations g.1104A $>\mathrm{C}+$ g.1111C $>\mathrm{T}+\mathrm{g} .1121 \mathrm{C}>\mathrm{G}$, the first two located at IVS4-15A>C and IVS4-8C $>\mathrm{T}$, respectively, and the third in the first codon of exon 5 leading to the putative missense p.D183E was identified (Figure 1B).

As those nucleotide changes, now named IVS4-Ex5, were located within intron 4 /exon 5 junction sequence and could interfere with the normal acceptor splice site, they were investigated on their influence upon the formation of the correct CYP21A2 transcript using mini-
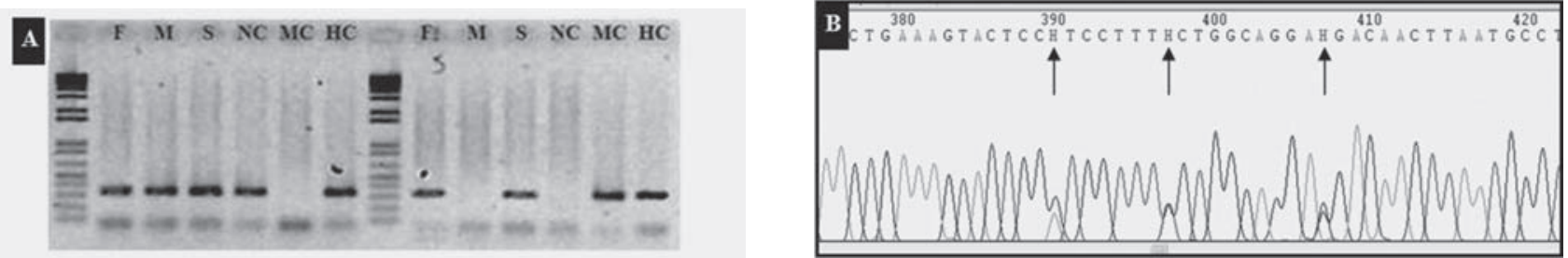

Figure 1. (A) ASO-PCR results for p.V281L. Amplified fragments were separated on a 1\% agarose gel. Left - the V281 normal primer; right - L281 mutant primer. F - father; M - mother; S - child; NC - normal control; MC - mutant control; HC- heterozygous control. The 1-kb Plus DNA ladder (Invitrogen) was used as marker. (B) DNA sequencing data of the male child showing part of intron 4 - exon 5 boundary region. The arrows indicate the nucleotide changes. 
gene constructions. The cDNAs resulted from the transcription of minigene containing CYP21A2 exons 3 to 6 did not show any sequence difference between the normal control and the variant constructs (Figure 2).

\section{DISCUSSION}

A male child presenting high levels of 17-OHP in the neonatal screening was conducted to molecular investigation for CYP2IA2 mutations.

CYP21A2 gene was screened for $30-\mathrm{kb}$ deletion, large gene conversion and pseudogene-derived mutations. The paternal inherited allele showed p.V281L. This mutation is pseudogene-derived and it is known to present a residual enzymatic activity of $20-50 \%$ (18, 19). It is considered the most common Caucasian mutation among cases of NC form of 21-OHD (20). The maternal allele presented three nucleotide changes, named IVS4-Ex5. These changes are also pseudogenederived but had never been described in the active CYP21A2 gene, except one report on the D183E mutation in exon 5 (21). As no other sequence variations were observed in the maternal allele the IVS4-Ex5 nucleotide change was considered as a result of a rare microconversion mutational event.

The exon 5 g.1121C>G causing the mutation p. D183E had been studied before and did not affect the normal enzymatic activity, therefore was considered a polymorphism in CYP21A2 (19). However, the IVS4-
Ex5 nucleotide changes together were not investigated. Due to their location in the acceptor splice site region, they could interfere with the normal splicing process. Minigene in vitro experiments demonstrated that the recognition of the intron 4 acceptor splice site by the spliceosome occurred in both wild-type and mutant sequences. Therefore, neither p.D183E reduces enzymatic activity nor IVs4-Ex5 nucleotide changes alter normal transcription indicating a normal variant for the allele.

Elevated 17-OHP blood level is normally used as an indicator of CAH. In general, the technique of analyzing 17-OHP in neonatal screenings is radioimmunoassay in filter-paper blood samples $(6,7)$. It has been discussed by several authors that this procedure generate a high rate of positive results attributable to physiological reasons and to cross-reactions with steroids other than 17-OHP, especially in preterm neonates $(9,10)$. In addition, Bachega et al. (5) studied obligate heterozygote parents of patients with 21-OHD and they observed that 11 of $19 \mathrm{p} . \mathrm{V} 281 \mathrm{~L}$ carriers presented elevated ACTH-stimulated 17-OHP levels. Therefore we consider that this study illustrate such technical artifact where a p.V281L carrier newborn was considered as having 21-hydroxylase deficiency and treated. Concluding, the child described here cannot be considered affected with $21-\mathrm{OHD}$, although a rare allelic variant had been identified in compound heterozygosis with p.V281L.

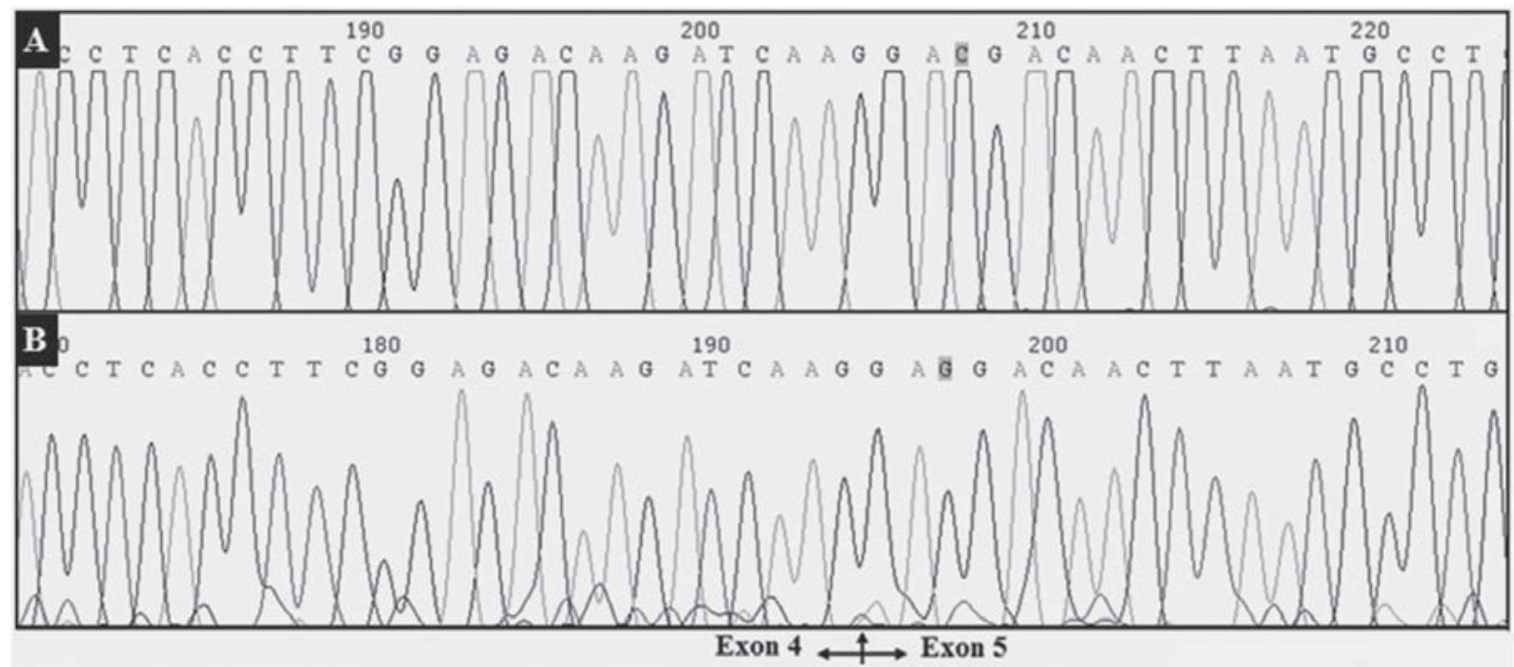

Figura 2. Eletropherogram showing part of the cDNA sequence formed by exon 2 to exon 6. (A) wild-type minigene sequence; (B) sequence of minigene containing the IVS4-Ex5 nucleotide changes. The grey box denote the GAC> GAG transversion in codon 183 (p.D183E). Arrows indicate the exon 4 - exon 5 junction. 
In summary, the molecular study presented here contributed to define the normal phenotype of a boy considered as 21-OHD in neonatal screening. Therefore, this case illustrates the importance of molecular biology as feasible tools to confirm presumed altered neonatal screening results. Furthermore, this report provided new insights concerning the function of pseudogene-derived alterations in intron 4 / exon 5 acceptor splice site region. Knowledge about the functional effects of alterations improves a correct genotype-phenotype correlation. The molecular investigation pointed out this case as a heterozygous carrier directing clinical management.

Acknowledgments: The authors would like to thank Profa. Dra. Carmen Veríssima Ferreira and Rodrigo Augusto da Silva for their assistance. This research was supported by Fundação de Amparo à Pesquisa do Estado de São Paulo-FAPESP (proc. $\mathrm{n}^{\circ}$ 2005/00981-5) and personal grant to FCS (proc. $\mathrm{n}^{\circ}$ 2003/01785-0). The authors thank the family studied for agreeing to participate in this research. No potential conflict of interest relevant to this article was reported.

\section{REFERENCES}

1. White PC, Speiser PW. Congenital adrenal hyperplasia due to 21-hydroxylase deficiency. Endocr Rev. 2000;21:245-91.

2. Riepe FG, Sippell WG. Recent advances in diagnosis, treatment, and outcome of congenital adrenal hyperplasia due to 21-hydroxylase deficiency. Rev Endocr Metab Disord. 2007;8(4) :349-63.

3. New MI, Lorenzen F, Lerner AJ, Kohn B, Oberfield SE, Pollack MS, et al. Genotyping steroid 21-hydroxylase deficiency: hormonal reference data. J Clin Endocrinol Metab. 1983;57:320-6.

4. Azziz R, Hincapie LA, Knochenhauer ES, Dewailly D, Fox L, Boots LR. Screening for 21-hydroxylase-deficient nonclassic adrenal hyperplasia among hyperandrogenic women. Fertil Steril. 1999;72:915-25.

5. Bachega TA, Brenlha EM, Billerbeck AE, Marcondes JA, Madureira G, Arnhold IJ, Mendonca BB. Variable ACTH-stimulated 17-hydroxyprogesterone values in 21-hydroxylase deficiency carriers are not related to the different CYP21 gene mutations. J Clin Endocrinol Metab. 2002;87(2):786-90.

6. Pang S, Hotchkiss J, Drash AL, Levine LS, New MI. Microfilter paper method for 17-hydroxyprogesterone radioimmunoassay: its application for rapid screening for congenital adrenal hyperplasia. J Clin Endocrinol Metab. 1977;45:1003-8.

7. Valentino R, Tommaselli AP, Rossi R, Lombardi G, Varrone S. A pilot study for neonatal screening of congenital adrenal hyperplasia due to 21-hydroxylase and 11-hydroxylase deficiency in Campania region. J Endocrinol Invest.1990;13: 221-5.

8. Janzen N, Peter M, Sander S, Steuerwald U, Terhardt M, Holtkamp U, Sander J. Newborn screening for congenital adrenal hyperplasia: additional steroid profile using liquid chromatography-tandem mass spectrometry. J Clin Endocrinol Metab 2007; 92(7): 2581-89.
9. Pang S, Murphey W, Levine LS, Lorenzen F, Levy D, Lerner AJ, Rondanini GF, Dupont B, New MI. A pilot newborn screening for congenital adrenal hyperplasia in Alaska. J Clin Endocrinol Metab 1982; 55: 413-20.

10. Nordenström A, Wedell A, Hagenfeldt L, Marcus C, Larsson A. Neonatal screening for congenital adrenal hyperplasia: 17-hydroxyprogesterone levels and CYP21 genotypes in preterm infants. Pediatrics 2001; 108(4): E68.

11. Cardoso CB, Fonseca AA, Oliveira Mde F, Pereira BB, Guimarães $M M$. Congenital adrenal hyperplasia newborn screening: Rio de Janeiro experience. Arq Bras Endocrinol Metabol 2005; 49(1): 112-19.

12. Silveira EL, dos SE, Bachega TA, van der Linden Nader I, Gross $\mathrm{JL}$, Elnecave RH. The actual incidence of congenital adrenal hyperplasia in Brazil may not be as high as inferred-an estimate based on a public neonatal screening program in the state of Goiás. J Pediatr Endocrinol Metab 2008; 21(5): 455-60.

13. Sambrook J, Fritsch EF, Maniatis TE. Molecular Cloning, a Laboratory Manual. New York: Cold Spring Harbor.1989.

14. Araujo M, Sanches MR, Suzuki LA, Guerra-Jr G, Farah SB, De Mello MP. Molecular analysis of CYP21 and C4 genes in Brazilian families with the classical form of steroid 21-hydroxylase deficiency. Braz J Med Biol Res. 1996;29:1-13.

15. Wilson RC, Wei JQ, Cheng KC, Mercado AB, New MI. Rapid deoxyribonucleic acid analysis by allele-specific polymerase chain reaction for detection of mutations in the steroid 21-hydroxylase gene. J Clin Endocrinol Metab 1995; 80(5): 1635-40.

16. Lau IF, Soardi FC, Lemos-Marini SH, Guerra-Jr G, Baptista MT, De Mello MP. H28+C insertion in the CYP21 gene: a novel frameshift mutation in Brazilian patient with the classical form of 21-hydroxylase deficiency. J Clin Endocrinol Metab. 2001;86: 5877-80.

17. Higashi $Y$, Yoshioka H, Yamane M, Gotoh O, Fujii-Kuriyama Y. Complete nucleotide sequence of two steroid 21-hydroxylase genes tandemly arranged in human chromosome: a pseudogene and a genuine gene. Proc Natl Acad Sci USA. 1986;83:2841-5.

18. Wilson RC, Nimkarn S, Dumic M, Obeid J, Azar MR, Najmabadi $\mathrm{H}$, et al. Ethnic-specific distribution of mutations in 716 patients with congenital adrenal hyperplasia owing to 21-hydroxylase deficiency. Mol Genet Metab. 2007;90(4):414-21.

19. Tusie-Luna MT, Traktman P, White PC. Determination of functional effects of mutations in the steroid 21-hydroxylase gene (CYP21) using recombinant vaccinia virus. J Biol Chem. 1990;265(34):20916-22.

20. Higashi $Y$, Hiromasa T, Tanae A, Miki T, Nakura J, Kondo T, et al. Effects of individual mutations in the P-450(C21) pseudogene on the P-450(C21) activity and their distribution in the patient genomes of congenital steroid 21-hydroxylase deficiency. J Biochem. 1991;109(4):638-44.

21. Bachega TA, Billerbeck AE, Madureira G, Marcondes JA, Longui $\mathrm{CA}$, Leite MV, et al. Molecular genotyping in Brazilian patients with the classical and nonclassical forms of 21-hydroxylase deficiency. J Clin Endocrinol Metab. 1998;83(12):4416-9.

\section{Correspondence to:}

Maricilda Palandi de Mello

CBMEG-Unicamp

Caixa Postal 6010

13083-875 Campinas, SP

E-mail:mmello@unicamp.br 